\title{
Research on the Teaching Practice of the Folk Art Course in the Master of Arts in Inner Mongolia Agricultural University
}

\author{
Wenfeng Xue* \\ College of Materials Science and Art Design \\ Inner Mongolia Agricultural University \\ Hohhot, Inner Mongolia, China
}

\begin{abstract}
Folk art is the visual image carrier of folk culture. The professional education of Master of Arts in Colleges and universities can provide students with a deeper understanding of the excellent traditional culture of the Chinese nation. The folk art of Oroqen, Ewenki and Daur nationalities in Inner Mongolia is an important part of Chinese traditional art. This paper briefly describes the development of folk art at home and abroad, the significance of setting up folk art course for Master of Arts in Inner Mongolia Agricultural University, and the construction planning and teaching application of the course. The purpose is to guide students to understand the richness and diversity of Chinese folk art from the perspective of fine arts and design. Combined with the regional characteristics of cultural ecology and teaching practice in Inner Mongolia, students can be familiar with the artistic characteristics and cultural values of folk arts in Oroqen, Ewenki and Daur in Inner Mongolia. Through the flipped classroom and other teaching methods, this paper makes analogy and case analysis on the image modeling, craft style, material performance and aesthetic law of typical folk art of Oroqen, Ewenki and Daur nationality, so as to deepen students' multiple understanding of Chinese national cultural memory symbols and images, establish national cultural confidence, expand artistic creative thinking, and cultivate students' comprehensive quality and performance ability in modern art design by using folk art knowledge.
\end{abstract}

Keywords-Folk art; Inner Mongolia Agricultural University; Master of Arts; teaching practice

\section{THE DEVELOPMENT OF FOLK ART}

At the end of the 19th century, the "British Arts and Crafts Movement" was the first reflection and transformation of folk arts in Western society. Since German "Bauhaus" introduced folk art into colleges and universities in 1919, folk art has developed rapidly and spread from school to other social design fields in the form of studio. European countries, Japan and South Korea attach great importance to their own folk art, and set up a large number of Folk Art and Folk Museums. Colleges and universities attach great importance to the research of folk art and allocate special funds to support the construction of folk art courses.

Fund Project: National Social Sciences Fund Art Program: Research on folk art of Olunchun, Ewenki and Daur in hulunbuir region of Inner Mongolia (15EF178)

Project of Major Curriculum Construction for Graduate Students in Inner Mongolia Agricultural University: Research on Folk Arts (RC2000000466)
China's Central Academy of Fine Arts established the folk art specialty in the 1980s, and has now developed into a cultural heritage college. With the development of economy, China has transformed from a big manufacturing country into an innovative country. Colleges and universities all over the country pay more and more attention to the cultivation of talents with deep roots in traditional culture design. The former shrinking arts and crafts majors have sprung up like mushrooms. In recent years, Inner Mongolia Business \& Trade Vocational College, Vocational and Technical College of Inner Mongolia Agricultural University and Hohhot Minzu College have successively applied for arts and crafts majors in Inner Mongolia. In 2018, Inner Mongolia Normal University established the School of Arts and Crafts. And the above schools all set up courses related to folk art. At present, design majors in colleges and universities all over the country increase the publicity of the "craftsmanship spirit" in folk art, and give multiple policy support. In 2019, the professional talent training program of Master of Arts in Inner Mongolia Agricultural University took folk art course as an elective course for second-year graduate students, which has a good role in promoting students to learn art materials from life, inherit and learn Chinese traditional culture.

\section{The SignificANCE of Folk ART CURriculum}

Folk art patterns, murals, paper-cuts and other art forms appeal to both refined and popular tastes. It is a visual art summarized and created by the working people in the longterm production process to meet their own living needs with their hard-working hands and wisdom. The Master of Arts in Inner Mongolia Agricultural University is divided into three major directions--environmental design, northern nomadic ethnic arts and crafts and furniture design. The research of folk art is the abundant supplies for the application of visual elements in the discipline development of Master of Arts. Setting up courses has a direct role in understanding Chinese traditional culture and consolidating the basic quality of design major. The research of folk arts can cultivate students' creative thinking and aesthetic concepts, improve their sense of identity with national culture, and realize the inheritance of the traditional culture in colleges and universities. In addition, setting up folk arts courses in the training program of Master of 
Arts plays an important role in the supplement of aesthetic education resources and the diversity of the classroom teaching forms.

With the increasing concern of the society on folk arts, the academic research on its survival status and development prospects is more and more in-depth, and the status and role of folk art curriculum in the construction of art design education system with Chinese national characteristics is becoming increasingly prominent. In the professional education and teaching of Master of Arts, the teaching of folk arts knowledge has gradually become a trend. Based on the original teaching plan, many undergraduate and postgraduate courses of art design in many colleges and universities in China have been added, such as the basic theoretical courses of art appreciation, folk patterns and art history theory, which are closely related to folk arts. In the teaching practice of the Master of Arts, Inner Mongolia Agricultural University pays attention to the effective connection between the folk art courses and other professional courses, and increases the teaching content of the folk arts of Oroqen, Ewenki and to actively promote a comprehensive and in-depth understanding of the richness and humanistic connotation of Chinese folk art. The major of Master of Arts in Inner Mongolia Agricultural University teaches folk arts courses from the perspective of cultural heritage, considers the course construction in terms of teaching methods, teaching practice and teaching content, describes the regional characteristics of Chinese folk art in combination with the research results of Oroqen, Ewenki and Daur ethnic groups in Inner Mongolia, and explores the problems in the assessment method and teaching practice of folk arts courses, which have practical significance for improving the effectiveness of professional education and folk art teaching for Masters of Arts.

\section{CONSTRUCTION PlanNing OF FOLK ART CURRICUlum}

The Master of Arts in Inner Mongolia Agricultural University set up the folk arts courses to let graduate students understand folk customs and traditional Chinese folk art, which is the premise and foundation of folk art learning. Only by putting folk art in the overall context of Chinese folk culture to explain and applying the research results of teachers' folk art field survey to the teaching practice, can the boring book knowledge and concepts become vivid cases combining theory with practice, which will be easier for students to understand and master.

In the past two years, folk art course has been listed as a professional elective course for the Master of Arts of the School of Materials Science and Art Design in Inner Mongolia Agricultural University. Xue Wenfeng is responsible for the construction of the course, and the folk art course group is established. The members of the group belong to different age groups of 60, 70 and 80 . All of them have experience in folk art research and case practice. The team of teachers embodies the characteristics of mentoring among the young, middle-aged and the elderly. The specific teaching content of the folk art course is divided into eight knowledge units: northern nomadic folk art, northern nomadic folk sculpture, northern nomadic metal crafts, northern nomadic folk paper cutting, northern nomadic folk mural, northern nomadic folk embroidery and other northern nomadic folk art.
The folk art course mainly adopts the teaching methods of theory explanation, flipped classroom, skill demonstration, typical material comparison and excellent practice case analysis and evaluation. The recommended textbooks and references for this course include Mongolian Art Research edited by Mr. Amur Batu, Chinese Folk Art Research compiled by the Institute of Fine Arts of the Chinese Academy of Art, Chinese Folk Art written by Liu Shijun, Dictionary of Chinese National Folk Cultural Relics edited by Song Zhaolin and Gao $\mathrm{Ke}$, Inner Mongolia Ethnic Customs dited by Lin Gan, Oroqen Nationality-- -Safari - Settlement $\bullet$ Development dited by Du Yonghao, olk Art of Ewenki and Primitive Art of Hunting Nationality published by Inner Mongolia Culture Press. The folk art course of Inner Mongolia Agricultural University is also a supplement to the traditional Chinese pattern course previously taught in the university, and is a course after the adjustment of the talents training plan for the Masters of Arts. Judging from the teaching effects of the past 8 years, the achievement of the teaching objectives, the attention of the knowledge points, the satisfaction of the teaching effect and the active participation of students in the implementation of practical cases under the guidance of teachers, more than $90 \%$ of the students have mastered effective learning methods and aesthetic principles of folk art, and have acquired solid theoretical knowledge and professional skills of folk art system. In the follow-up training of related professional quick questions in class, students have sufficient emotional experience of design, and the detection effects of their folk art works are good.

The members of the folk art curriculum group have presided over a total of 9 projects, such as National Social Science Fund and Art Projects, the Art Creation Project of the Major Historical Themes in Inner Mongolia, the 13th Five-year Education Science Planning Project in Autonomous Region, and school social science and education reform projects. Based on the platform of the Institute of Arts and Crafts in Inner Mongolia Agricultural University, the lecturer has accumulated rich subject research and teaching experience, and has sufficient teaching case materials, has established a folk art curriculum system that highlights the Mongolian and Oroqen, Ewenki, and Daur ethnic groups and the advantages of Mongolian graphic image research. However, in the teaching practice, it is found that many of the folk art styles in Inner Mongolia and even in China have been severely squeezed and even faced the risk of being lost due to the development of modern industry and mass production of products. Many old folk art craftsmen have passed away. Traditional folk art has changed the way of inheritance in modern life due to changes in usage habits, which has affected the audience of folk art. It is required that teachers in the folk art curriculum construction and practical application, should do a good job in the study of folk art inheritance and innovation based on the reality, extract the valuable artistic essence of folk art, find the cultural gene of traditional folk art, and develop the folk art style with sustainable development in culture to adapt to people's appreciation and use of folk art today. The curriculum construction of folk art should also combine folk art and the spread of intangible cultural heritage closely, assist in the targeted poverty alleviation project in the construction of beautiful rural areas in China, form a win-win cooperative 
industry-university-research mechanism between Inner Mongolia Agricultural University and local governments, and mobilize the art design innovation of folk art graduate students to connect with the folk art handicraft workshops in villages and towns with local characteristics. We should excavate the local cultural tourism products, establish brand awareness, and let folk art design serve the local economic development.

\section{PRACTICE APPLICATION OF FOLK ART TEACHING}

According to the goal and content of the course construction, the application of folk art curriculum teaching practice needs to improve the rules and regulations of the curriculum teaching management and quality assurance and the details of the implementation plan, form a curriculum system that conforms to the Master of Arts major in Inner Mongolia Agricultural University, optimize the teaching content of the curriculum, scientifically demonstrate the proportion of the curriculum practice content, and carry out the implementation of typical practice case teaching. We should strengthen the construction of digital network system of folk art courses and make full use of modern information technology to update teaching implementation methods. On the premise of improving the teaching level of the teachers, the folk art course group of the Master of Arts in Inner Mongolia Agricultural University designs the teaching content according to the characteristics and positioning of the course, introduces the frontier of folk art and teaching achievements into the classroom and teaching practice, inspires students to seek innovative points in the design of the course proposition of folk art research, simultaneously follows up the teaching methods and teaching evaluation system to mobilize students' innovative spirit of thinking and practice. Teachers should actively compile and use excellent teaching materials, enrich teaching resources, strengthen the construction of practical training bases inside and outside the school, make good use of the existing woodworking practice factory of the school to design and produce cultural and creative products and tourist handicrafts with national characteristics, and make full use of DingTalk, Tencent Conference, ZOOM and other online teaching methods that are not limited by time and place to communicate with students and answer questions. We also need to study the implementation scheme of micro-classes and MOOC of folk arts to adapt to the network teaching of knowledge and the service function of students' independent learning, discuss the possibility of folk arts as an elective course for the traditional culture in the whole school, and deepen and further improve the teaching level of graduate students of design majors in our school through the continuous improvement and deepening of folk art teaching practice.

The lecturer of the folk art course should be the teacher with "both high knowledge and moral integrity", to practice internal skills, continuously enrich teaching experience, improve teaching levels and academic attainments, so that their teaching characteristics of folk art courses become more distinct. In the process of deepening the reform of folk art course content and curriculum system and improving the teaching quality, teachers should timely grasp the frontier ideas and novel teaching concepts of the subject through communication and observation inside and outside the school, pay attention to the updating and improvement of teachers' knowledge structure, and strengthen the construction of training links and training bases. Folk art courses must pay attention to the cultivation of teaching practice, encourage students to participate in social practice, investigation and research and encourage teachers to standardize teaching links and improve teaching documents, and fully reflect the results of teaching reform. In addition, relying on the training objectives and plans of graduate students in Inner Mongolia Agricultural University, teachers should rationally design the curriculum content, explore the teaching and teaching laws of design majors, scientifically arrange the mutual promotion between theoretical knowledge and practical skills, and increase the content teaching of frontier information at the level of basic research. Folk art course can promote the development of students' comprehensive abilities by continuously improving teaching methods, strengthening the goal orientation of ability training and quality education, effectively tracking the teaching methods and teaching evaluation standards, and flexibly using the practical case teaching method.

The folk art course guides graduate students to understand the richness and diversity of folk art of nomadic ethnic groups in northern China from the perspective of fine arts and design, and closely connects with the regional characteristics of cultural ecology in Inner Mongolia, so that students are familiar with the artistic characteristics and cultural values of folk arts of Oroqen, Ewenki, Daur and Mongolian Folk, focusing on the interpretation of folk carvings, folk papercutting, pommel horse utensils, metal crafts, felt decoration, temple murals, cultural context of embroidered felt art, production shapes, materials types and artistic expression techniques, and the image modeling, artistic style material application process and aesthetic rule of typical folk arts of Oroqen, Ewenki, Daur and Mongolian are analyzed by case analogy. The difficulty of this course is the verification of the similarities and differences between the historical dysfunction and integration of the folk arts of Oroqen, Ewenki, Daur and the folk arts and crafts of Mongolian. The practical application of folk art course teaching can also be carried out in-depth research in accordance with the procedures of "investigation and selection, course demonstration, scheme formulation, practical research, exchange and summary, and textbook compilation". In this course, teachers and students can use their spare time to select, catalog, mark, and locate typical case scenarios through satellite navigation and field surveys, and then analyze the construction of theoretical knowledge and material collection of the case teaching objects through literature retrieval, go to the field to survey and draw sketches, extract the image modeling with regional characteristics and reflecting the characteristics of folk art, and finally draw for the expression of creative thinking. In the practical operation of the course, students use the "brainstorming method" to carry out multi-dimensional demonstration and summary of different creative ideas, constantly optimize the scheme design, and find the historical origin of the interaction of the folk arts between Oroqen, Ewenki, Daur and Mongolian. Folk art courses put forward practical teaching and practical application schemes on the basis of theoretical analysis, comparison and reference, data analysis, and summary. 
The teachers of folk arts have collected more than 50 academic journal papers, dissertations and works required for the teaching of relevant courses, including the pictures and text materials about teaching reform, curriculum setting and teaching standards for discipline development of the folk fine arts and basic fine arts courses, which were taken during the early business exchanges of colleges and universities inside and outside the region. Bothe the teachers in the folk art course group who have sufficient time for lesson preparation, strong theoretical and professional quality, and the teaching materials and teaching equipment reserved for the course can meet the requirements of the course and complete the course smoothly on schedule. In addition, the main teachers of the folk arts course group are all front-line teaching and scientific research personnel with the background of fine arts and design. They have been engaged in the research and practice of folk arts and art design in ethnic minority areas for a long time. The different professional backgrounds of teachers are conducive to the formation of complementary disciplinary advantages and the completion of the teaching tasks and teaching practice of the folk arts course for Masters of Arts major in Inner Mongolia Agricultural University.

\section{CONCLUSION}

The teaching of the folk arts course for Masters of Arts in Inner Mongolia Agricultural University has always been based on the value of "art comes from life" from the Literature and Art Forum in Yan'an, emphasizing the teaching guidance and creation concept of "art comes from life, higher than life, and serves the public". In the teaching practice, we always carry through the Chinese socialist aesthetic education thought, carry out various of teaching activities by using the technical means of modern education, so as to maximize students' learning interests and the teaching effect. At the same time, on the basis of the selection of excellent teaching materials, actively compile the folk art teaching materials of design major for graduate students in Inner Mongolia that are suitable for the development of discipline characteristics of colleges and universities in Inner Mongolia. These teaching practice measures are designed to create an equal and interactive classroom atmosphere, truly enable students to flexibly apply what they have learned into practice, and cultivate students' ability to find and solve problems. It is proved that focusing on the accumulation of experience and methods in the formation of folk art knowledge, focusing on the integration of knowledge and skills inside and outside the curriculum, strengthen students' understanding of Chinese traditional humanistic spirit and humanistic care, and grasp the pulse of the times and the frontier information of design, which are very important for the folk arts to guide students to be a person with Chinese traditional cultural aesthetic consciousness, pioneering and creative thinking, sense of responsibility and leading role, and to enable students to use folk art knowledge to cultivate comprehensive quality and ability in modern art design.

\section{ACKNOWLEDGMENT}

Fund Project: National Social Sciences Fund Art Program: Research on folk art of Olunchun, Ewenki and Daur in hulunbuir region of Inner Mongolia (15EF178); Project of Major Curriculum Construction for Graduate Students in Inner Mongolia Agricultural University: Research on Folk Arts (RC2000000466)

\section{REFERENCES}

[1] Wang Yan.The transformation of the aesthetic values of the folk art of the three minorities in Hulunbuir [J]. Beauty and time(Go), 2016(6):2428. (In Chinese).

[2] Liu Xiaojie. Teaching reform and practice of folk art course for art design major in colleges and universities [J]. Arts Education, 2017(7):154-155. (In Chinese).

[3] Shen LE. Understanding and practice of Chinese folk art teaching in colleges and universities [J]. Journal of Hefei Normal University, 2018(1):115-118. (In Chinese).

[4] Yang Xianwei. A summary of the research on the development of folk art curriculum resources [J]. Research on Fine Arts Education, 2018(1):94-95. (In Chinese)

[5] Zou Ronghua. On the development and application of local folk art curriculum resources [J]. A Comparative Study of Cultural Innovation, 2018(1):176-177. (In Chinese). 